\title{
Cadmium Bioaccumulation in Yellow Foxtail (Setaria glauca L. P. Beauv): Impact on Seed Head Morphology
}

\author{
D. K. Kosma*, J. A. Long, and S. D. Ebbs \\ Department of Plant Biology \\ Southern IIlinois University Carbondale \\ Carbondale, Illinois 62901 USA
}

Received: November 18, 2003

Accepted: March 17, 2004

\begin{abstract}
Yellow foxtail (Setaria glauca L. P. Beauv) growing on a cadmium-contaminated site was sampled to determine the extent of cadmium bioaccumulation in aerial tissues and the impact of cadmium on growth and development. Water-extractable $\mathrm{Cd}$ concentrations in the soil ranged from 5.0 to $18.0 \mathrm{mg} \mathrm{L}^{-1}$. Aerial tissues contained elevated concentrations of Cd (16-48 $\mu \mathrm{g} \mathrm{g}^{-1}$ DW), with mean concentration ratios of $\geq 3.0$. Since foxtail frequently colonizes disturbed sites, the bioaccumulation of $\mathrm{Cd}$ in aerial tissues of foxtail suggests that wildlife feeding upon this plant species could be exposed to elevated Cd levels. A significant negative correlation $\left(r^{2}=0.98\right)$ was observed between water-extractable $\mathrm{Cd}$ in the soil and seed head length in foxtail, indicative of an adverse effect of $\mathrm{Cd}$ on reproductive development. This correlation further suggests seed head length as a biomarker for soluble $\mathrm{Cd}$ in contaminated soils.
\end{abstract}

KEYWORDS: Cadmium, bioaccumulation, biomarker, phytotoxicity

\section{INTRODUCTION}

Cadmium is an important environmental contaminant due to its toxicity and because it is accumulated in plants as an analog of zinc. Phytotoxicity resulting from $\mathrm{Cd}$ uptake has been described in numerous studies, most of which focus on the impact of $\mathrm{Cd}$ on vegetative growth and development (see Balsberg Påhlsson [1] and Das et al. [2] for reviews). Such studies typically discuss phytotoxicity in terms of decrease in tissue biomass, chlorosis, and effects on specific physiological (e.g., xylem transport) or biochemical (e.g., nitrogen fixation) processes. Fewer studies have focused on the impact of $\mathrm{Cd}$ on development of reproductive tissues. From an ecological perspective, $\mathrm{Cd}$ bioaccumulation in plant

* Correspondence to: D. K. Kosma, 1-618-536-2331, badenya22@yahoo.com tissues may also pose a risk to wildlife in terrestrial food webs.

The Crab Orchard National Wildlife Refuge (CONWR), near Marion, IL (USA) was added to the National Priorities List in 1987, due to contamination arising from decades of industrial activity. Cadmium is among the pollutants that the U.S. Fish and Wildlife Service has identified on specific sites within the refuge, particularly in proximity to a sewage treatment plant at the refuge (M. Vick, personal communication). Cadmium was introduced to the soil in part from nearby plating operations. The site has been colonized by native and naturalized plant species and likely serves as a foraging area for wildlife at CONWR. A dominant plant species on the site is yellow foxtail (Setaria glauca L. P. Beauv). The objectives of this study were to examine the effect of $\mathrm{Cd}$ contamination on yellow foxtail in terms of tissue bioaccumulation and the impact on morphology. 


\section{MATERIALS AND METHODS}

This study was conducted on a contaminated site at the Crab Orchard National Wildlife Refuge (CONWR), near Marion, Illinois, USA. The site contains three primary contaminants, PCBs, PAHs, and $\mathrm{Cd}$ emanating in concentric rings from a point source on the site. Data on contaminant distribution at the site provided by the U.S. Fish and Wildlife Service (M. Vick, personal communication) allowed for the identification of a zone containing only $\mathrm{Cd}$ contamination, with total soil $\mathrm{Cd}$ concentrations of up to $400 \mu \mathrm{g} \mathrm{g}^{-1} \mathrm{DW}$. The data obtained for this study was collected from a north-south transect across this Cdcontaminated area.

A dominant species $(>75 \%$ ground cover) in the Cd-contaminated area during 2001 was yellow foxtail, Setaria glauca L., P. Beauv (=Setaria pumila (poir.) Roem \& Schult). Foxtail plants of a similar age class were selected from five random $1-\mathrm{m}^{2}$ plots along the transect. Within each plot, ten individual stalks with developed seed heads were randomly selected and harvested. The height of the stalk from base to the tip and the length of the seed head were measured. A composite soil sample was also collected from the upper $100 \mathrm{~mm}$ of the soil in the plot.

Harvested seed heads were dried to constant mass at $60^{\circ} \mathrm{C}$. The ten samples from each plot were combined to form a composite sample and ground to a fine powder. Samples $(5 \mathrm{~g})$ were ashed in a muffle furnace by gradually increasing the temperature from $25^{\circ}$ to $450^{\circ} \mathrm{C}$ over a $1.5 \mathrm{hr}$ period, followed by $2 \mathrm{hr}$ at $450^{\circ} \mathrm{C}$. The ash was re-suspended in $20 \mathrm{~mL}$ of aqua regia $\left(\mathrm{HCl}: \mathrm{HNO}_{3}, 3: 1 \mathrm{v} / \mathrm{v}\right)$ and diluted 1:20 with deionized water for analysis via graphite furnace atomic absorption spectroscopy (GFAA, Perkin-Elmer model 4100ZL, Cupertino, CA). The soil samples from the contaminated zone were sieved to $<5 \mathrm{~mm}$ and oven dried to constant mass. Extraction of a $5 \mathrm{~g}$ subsample of soil was performed with water $(1: 1 \mathrm{w} / \mathrm{v})$ overnight on a shaker. The soil extract was recovered by vacuum filtration using No. 42 Whatman filter paper followed by filtration through a $0.45 \mu \mathrm{m}$ Millipore filter. The soil extract was also analyzed for Cd via GFAA. Regression analysis of the data was performed using SPSS for Windows (Version 11, SPSS, Inc)

\section{RESULTS AND DISCUSSION}

In the United States, the range of total cadmium levels for contaminated surface soils in sludge-amended, irrigated, or fertilized farmland is $2.6-8.3 \mathrm{mg} \mathrm{L}^{-1}$ total, with some sites showing significantly higher concentrations [3]. The water extractable cadmium level in the soil from the study site ranged from 4.9-18.0 $\mathrm{mg} \mathrm{L}^{-1}$, was nearly double the range of total $\mathrm{Cd}$ in soil. Cadmium concentrations in the harvested foxtail tissues were loosely correlated $\left(r^{2}=\right.$ 0.31 with extractable soil Cd (Figure 1 ), but this correlation was stronger $\left(r^{2}=0.93, p<\right.$ 0.04 ) if a single inconsistent data point was excluded. This data point was from a sample taken from the extreme northern edge of the transect, farthest from source of contamination. The reason for this inconsistency cannot be explained, but could possibly relate differences in growth or seed maturity between these plants and those obtained from the other plots. Tissue concentration ratios (CRs), expressed as the ratio of tissue concentration (DW) to waterextractable $\mathrm{Cd}$, were $\geqslant 3.0$ for all data points except the inconsistent data point $(C R=1.0)$. While there was no correlation between water-extractable $\mathrm{Cd}$ and stalk height $\left(r^{2}=0.04\right)$, there was a significant negative correlation $\left(r^{2}=0.98, p<0.01\right)$ between extractable $\mathrm{Cd}$ and seed head length (Figure 2).

Yellow foxtail is widely distributed throughout North America following its introduction from Eurasia in the early $19^{\text {th }}$ century. As a naturalized weedy species, foxtail is among the first plant species to colonize disturbed landscapes. At the time this study was conducted, yellow foxtail represented $>75 \%$ of the ground cover on the Cd-contaminated site and was ubiquitous in the areas surrounding the site. Vegetative tissue of yellow foxtail can serves as forage for wildlife prior to flowering in early summer. Seeds of yellow foxtail also serve as a food source for a variety of bird species.

There is little current literature on the bioaccumulation and phytotoxicity of heavy metals in foxtail. The concentration ratios observed here indicated that $\mathrm{Cd}$ 


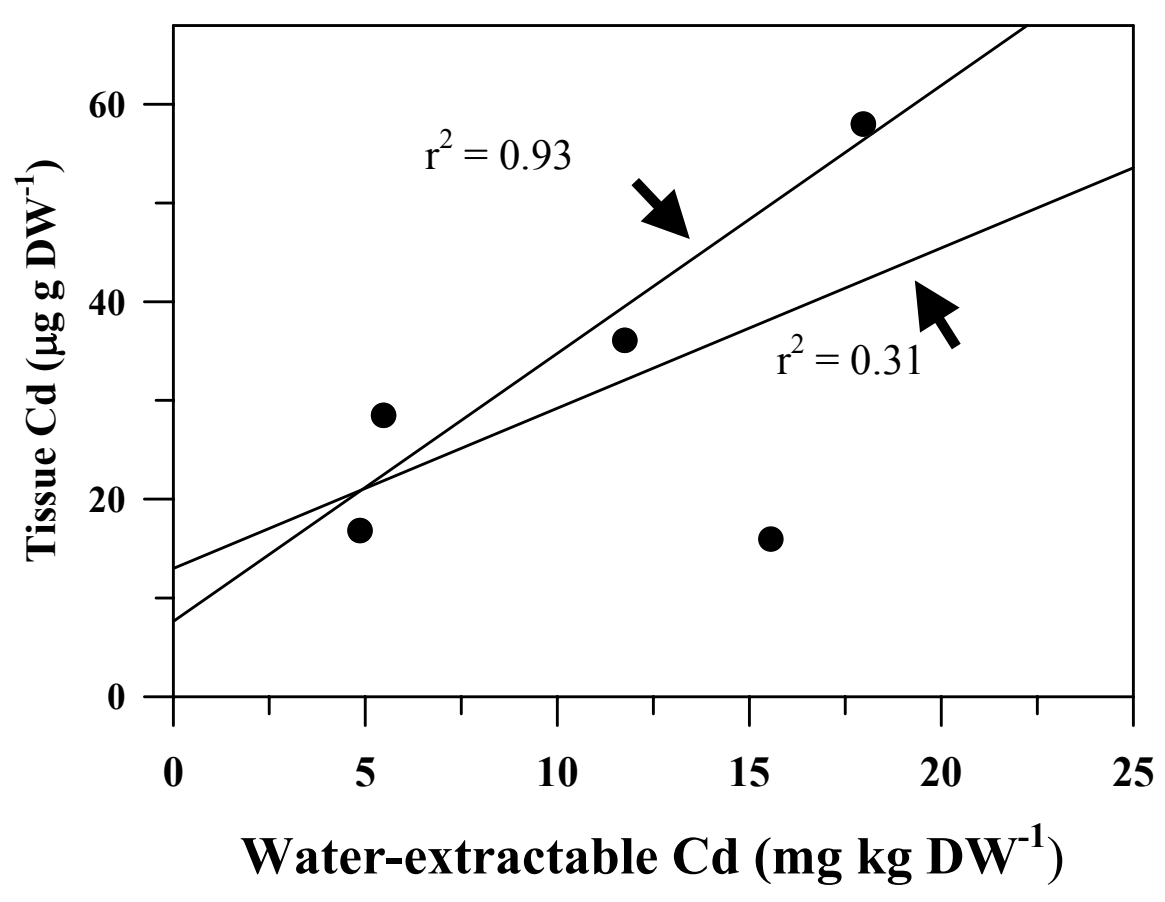

Figure 1. Relationship between water-extractable $\mathrm{Cd}$ in the soil and $\mathrm{Cd}$ concentrations in seed heads of yellow foxtail. Data represent the Cd content of a composite sample of 10 seed heads harvested within a given $1-\mathrm{m}^{2}$ plot. The two lines reflect the relationship between these two parameters when an inconsistent data value is included $\left(r^{2}=0.31\right)$ and excluded $\left(r^{2}=0.93\right)$.

bioaccumulated in the seed heads of foxtail. In most plants, cadmium is typically found at higher concentrations in vegetative tissue than in reproductive tissues like seeds. The Cd concentrations (16-48 $\left.\mu \mathrm{g} \mathrm{g} \mathrm{g}^{-1} \mathrm{DW}\right)$ for seed heads observed here are high in comparison to the typical concentrations reported for the aerial tissues of plants growing in Cd-contaminated soils [3]. Cadmium in grass tops growing on mining areas or sites impacted by industry or sludge amendment range from $<1.0$ to 8.2 $\mu \mathrm{g} \mathrm{g}^{-1} \mathrm{DW}$. A study of Cd accumulation in tissues of giant foxtail (Setaria faberii Herrm.) growing on sludge-amended soil $\left(1.5 \mu \mathrm{g} \mathrm{g}^{-1} \mathrm{DW}\right.$ total $\left.\mathrm{Cd}\right)$ reported that $\mathrm{Cd}$ concentrations were highest in roots but lowest in seeds [4]. However in other grasses such as wheat, the $\mathrm{Cd}$ concentration in leaves and grain becomes more similar as soil Cd concentrations increase [5].

The significant correlation between seed head length and water-extractable $\mathrm{Cd}$ demonstrated a possible adverse effect of elevated $\mathrm{Cd}$ concentrations on aspects of reproductive development in foxtail. The majority of studies addressing $\mathrm{Cd}$ phytotoxicity have considered effects on vegetative tissues or seed germination. Fewer studies have focused on the impact of $\mathrm{Cd}$ on morphology and reproductive processes [1]. Cadmium has been shown to induce cytological changes in tissues of foxtail millet (Setaria italica cv. Saket-4), resulting in anomalous epidermal and guard cell development $[6,7]$. These effects are due in part to Cd-induced damage of chromosomal material [8]. Adverse effects on cells have been observed at $\mathrm{Cd}$ concentrations of 1.5 to $10 \mathrm{mg} \mathrm{L}^{-1}$, similar to the range observed here. Cell wall metabolism and elongation are also inhibited by Cd [2, 9]. Related effects on cell division or elongation could have contributed to the decrease in seed head length observed here. Whether this decrease in seed head length also translated into a decrease in seed viability or plant fitness was not examined here. If this increased $\mathrm{Cd}$ concentration also decreased seed viability, then foxtail would not be expected to remain 


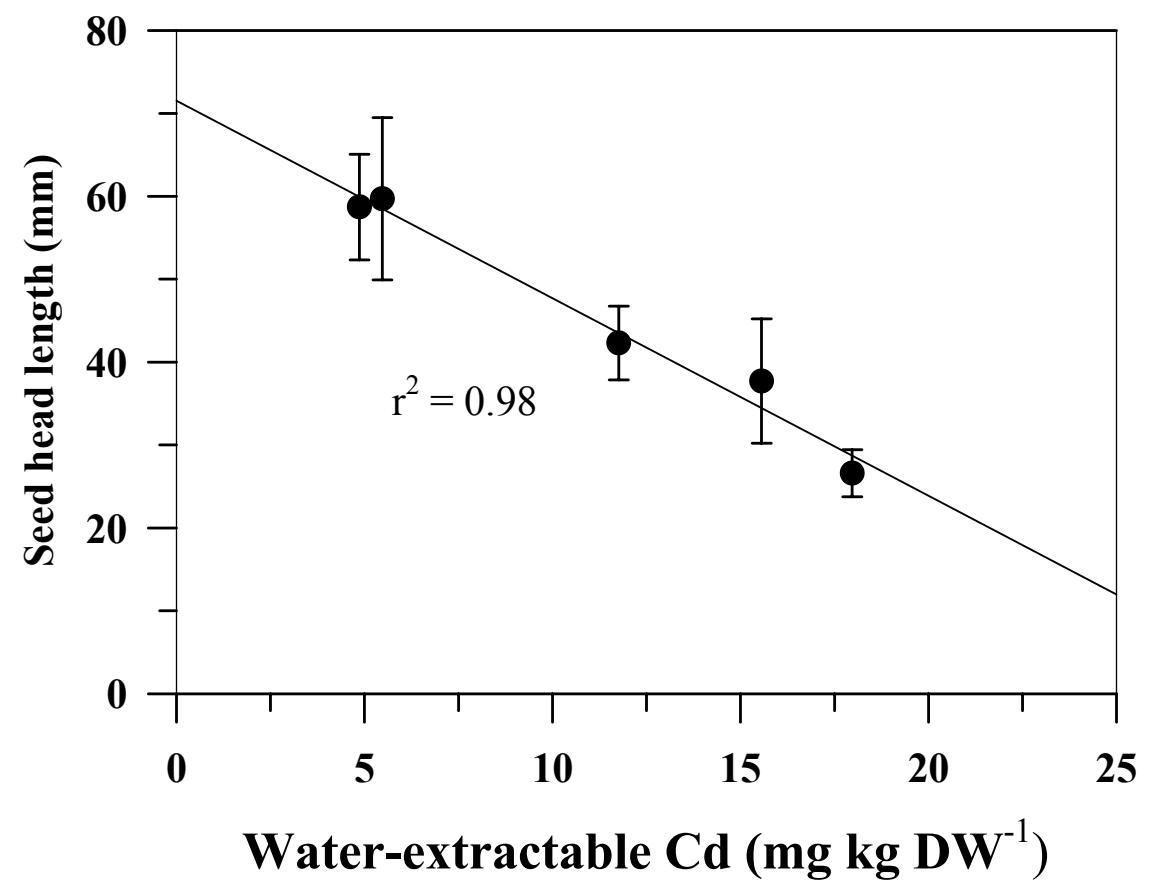

Figure 2. Relationship between water-extractable $\mathrm{Cd}$ in the soil and length of yellow foxtail seed heads. Data represent the mean and standard error for 10 stalks harvested from each $1-\mathrm{m}^{2}$ plot.

a dominant species on Cd-contaminated soils for long periods of time. In contrast, some studies have indicated that $\mathrm{Cd}$ does not have an adverse effect on seed germination and early development. Root elongation by ryegrass (Lolium perenne L.) is relatively unaffected by $\mathrm{Cd}$ concentrations up to $20 \mathrm{mg} \mathrm{L}^{-1}$ [10]. Germination of some tree seeds can increase in the presence of Cd [11].

The significant linear relationship between water-soluble $\mathrm{Cd}$ and seed head length implies that this morphological characteristic may provide a biomarker for soluble $\mathrm{Cd}$ in the soil. Several studies have sought to identify markers that accurately relate soil contaminant levels to tissue concentration or to some measurable biological characteristic. For example, ammonium nitrate extracts of soils spiked with $\mathrm{Cd}$ showed a significant correlation $\left(\mathrm{r}^{2}=\right.$ 0.97) with $\mathrm{Cd}$ concentrations in radish leaves [12]. Bioassays, such as the Tradescantia stamen hair assay [13] and the frequency of Vicia faba L. mitotic root micronuclei [14], have been utilized to assess the mutagenicity of various pollutants. Metabolic biomarkers, based upon synthesis of phytochelatins $[15,16]$ or peroxidase activity [17], have also been proposed as indicators of metal-related stress in plants.

The data presented here suggest that yellow foxtail could provide regulators and site managers with a tool for the biomonitoring of $\mathrm{Cd}$ contamination. The collection and analysis of soil and plant tissue samples is a critical aspect of ecological risk assessments. Seed head length would provide a simple, readily obtainable parameter to assess the distribution of soluble, vadose-zone $\mathrm{Cd}$ on a site. Such measurements could help focus subsequent soil and tissue sampling on areas with the greatest contamination. Moreover, data on $\mathrm{Cd}$ bioaccumulation in seed heads of foxtail could aid in identifying wildlife species potentially impacted by the Cd contamination present. For example, given that the foxtail distribution was continuous between the Cd-contaminated zone and surrounding areas at CONWR, wildlife feeding upon these seed heads may be exposed to elevated levels of $\mathrm{Cd}$. 
Potential exposure could be extrapolated based upon factors such as $\mathrm{Cd}$ concentration and feeding pattern, and total consumption. This particular site is relatively small $\left(<30,000 \mathrm{~m}^{2}\right)$ compared to the surrounding refuge area, so the impact on wildlife may be minimal as there have been no reported incidents of $\mathrm{Cd}$ toxicity to wildlife at CONWR. Nevertheless, these results suggest that other $\mathrm{Cd}$ contaminated areas colonized by foxtail may provide a pathway for $\mathrm{Cd}$ bioaccumulation in terrestrial food chains if the $\mathrm{Cd}$ contamination persists for an extended period of time. This trophic transfer would be dependent upon the continued presence of foxtail as a dominant plant species in that terrestrial ecosystem.

Additional field and greenhouse experiments are planned to confirm and extend these results, particularly with respect to the relationship between soluble and tissue Cd levels. Data here were based upon a single composite measurement of tissue $\mathrm{Cd}$ concentration. Establishing a quantitative relationship between these two factors will require more extensive sampling and analysis. The contribution of physical and environmental conditions such as slope aspect, soil mineralogy, soil moisture, and nutrient content will also have to be excluded to demonstrate that $\mathrm{Cd}$ is responsible for the alteration of seed head morphology. Future experiments with foxtail will also examine the effect of $\mathrm{Cd}$ on seed production and viability. One factor that was not evaluated in this work was whether the reduction in seed head size also reflected a difference in individual seed mass or viability. The reduction in seed head size could represent a form of stress response, but may be accompanied by a smaller number of viable seeds. This is a potentially important distinction that should be addressed.

\section{ACKNOWLEDGEMENTS}

The authors would like to thank Matt Vick of the U.S. Fish and Wildlife Service for providing access to the study site at Crab Orchard National Wildlife Refuge and data regarding the distribution of $\mathrm{Cd}$ at this site. The authors would also like to thank Dr. Alan Woolf and Cooperative Wildlife Research Laboratory at Southern Illinois
University Carbondale for conducting the GFAA analyses.

\section{REFERENCES}

1. Balsberg Påhlsson, A-M. (1989) Toxicity of heavy metals $(\mathrm{Zn}, \mathrm{Cu}, \mathrm{Cd}, \mathrm{Pb})$ to vascular plants. Water, Air, and Soil, Pollution 47, 287-319.

2. Das, P., Samantaray S., and Rout, G. R. (1997) Studies on cadmium toxicity in plants: A Review. Environmental Pollution 98, 29-36.

3. Kabata-Pendias, A. (2001) Trace Elements in Soils and Plants, 3rd ed. CRC Press, Boca Raton, FL.

4. Peles J. D., Brewer S. R., and Gary, W. (1998) Heavy metal accumulation by old-field plant species during recovery of sludge-treated ecosystems. American Midland Naturalist 140, 245-251.

5. Page, A. L., Bingham, F. T., and Chang, A. C. (1981) Cadmium. In Effects of Heavy Metal Pollution on Plants, Volume 1, Effects of Trace Metals on Plant Function, ed. N. W. Lepp, pp. 77109, Applied Science Publishers, London.

6. Pushpa, Y. and Srivastava, A. K. (1998) Cadmium induced mitotic anomalies in Hordeum vulgare and Setaria italica. Journal of Environmental Biology 19, 25-32.

7. Pushpa, Y. and Srivastava, A. K. (2000) Effect of heavy metal cadmium on the epidermal traits of some crops. Journal of Environmental Biology 21, 259-262.

8. Lamoureaux R.J. and Chaney W.R. (1977) Growth and water movement in silver maple seedlings affected by cadmium. Journal of Environmental Quality 6, 201-204.

9. Singh, O. P. and Sharma, A. (1980) Effect of certain metallic pollutants on plant genetic systems. Nucleus 23, 1529.

10. Wong, M. H. and Bradshaw A. D. (1982) A comparison of the toxicity of heavy metals, using root elongation of rye grass, Lolium perenne. New Phytologist 91, 255-261.

11. Scherbatskoy, T., Klein, R. M., and Badger, G. J. (1987) Germination responses of forest tree seed to acidity and metal ions. Environmental and Experimental Botany 27, 157-164. 
12. Symenoides, C., and McRae, G. C (1977) The assessment of plantavailable cadmium in soils. Journal of Environmental Quality 6, 120-123.

13. Rodrigues G. S., Ma, T-H., Pimentel D., and Weinstein, L. H. (1997) Tradescantia bioassays as monitoring systems for environmental mutagenesis: A review. Critical Reviews in Plant Sciences 16, 325-364.

14. Duan, C., Hu, B., Guo, T., Luo M, Xu, X., Chang, X., Wen, C., Meng, L., Yang, L., and Wang H. (2000) Changes of reliability and efficiency of micronucleus bioassays in Vicia faba after exposure to metal contamination for several generations. Environmental and Experimental Botany 44, 83-92.
15. Schat, H. and Kalff, M. M. A. (1992) Are phytochelatins involved in differential metal tolerance or do they merely reflect metal-imposed strain? Plant Physiology 99, 1475-1480.

16. Keltjens, W.G. and van Beuischem, M.L. (1998) Phytochelatins as biomarkers for heavy metal toxicity in maize: single metal effects of copper and cadmium, Journal of Plant Nutrition 21, 635-648.

17. Tahlil, N., Rada, A., Baaziz, M., Morel, J. L., El-Meray, M., and El-Aatmani, M. (1999) Quantitative and qualitative changes in peroxidase of Cucurbita pepo cultivars stressed with heavy metals. Biologia Plantarum 42, 75-80.

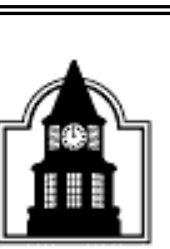

SOUthern Illinois University CaRBondale

http://www.siuc.edu
}

\section{Subscribe to the American Journal of Undergraduate Research}

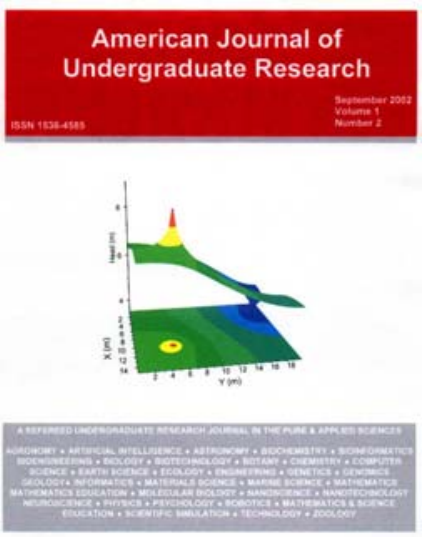

Individual Rate: \$20/year

Institutional Rate: \$40/year

Back Issues available at $\$ 5 /$ issue

AJUR Subscriptions

Physics 205

University of Northern lowa

Cedar Falls, lowa 50614-0150 USA

Cheques payable to "AJUR"

Institutions will be invoiced. 